\title{
Isolation of Epicatechin from the Stem Bark of Neocarya macrophylla (Sabine) Prance (Chrysobalanaceae)
}

\author{
${ }^{* 1}$ A. J. Yusuf, ${ }^{1}$ M. I. Abdullahi, ${ }^{2}$ A. M. Musa, ${ }^{2}$ A. K. Haruna, ${ }^{3}$ V. Mzozoyana and ${ }^{2}$ A. Sanusi \\ ${ }^{1}$ Department of Pharmaceutical and Medicinal Chemistry, Usmanu Danfodiyo University, Sokoto, Nigeria \\ ${ }^{2}$ Department of Pharmaceutical and Medicinal Chemistry, Ahmadu Bello University, Zaria, Nigeria \\ ${ }^{3}$ School of Chemistry and Physics, University of KwaZulu-Natal, Westville, Durban, South Africa
} [Corresponding Author: E-mail: amynajega@gmail.com; D:+234(0)8036386793]

\begin{abstract}
Neocarya macrophylla has a wide range of medicinal uses in traditional medicine. The aim of the study was to isolate and characterize compound from the stem bark of the plant. (-)-Epicatechin (a flavan-3-ol) was isolated from the ethylacetate soluble fraction of the methanol stem bark extract of the plant using a combination of silica gel and sephadex LH-20 column chromatography. The structure of the compound as (-)-epicatechin was confirmed on the basis of chemical test, 1D- \& 2D-NMR spectroscopy and comparison with existing data in literature. This is the first report of isolation of epicatechin from the stem bark of the plant.
\end{abstract}

Keywords: Neocarya macrophylla, stem bark, (-)-Epicatechin, NMR analysis

\section{INTRODUCTION}

The chrysobalanaceae family (first described by a botanist Robert Brown in 1816) is composed of 17 genera and about 525 species. They are mostly woody plants, shrubs or trees found in tropical and subtropical regions, mainly in the southern America (Yakandawala et al., 2010) with most of the species having edible fruits (Prance, 1988). There are few researches that revealed the chemical composition of the species of Chrysobalanaceae beyond genres Licania and Parinari. Flavonoidic compounds are known to play a very important role in the chemotaxonomy of the Chrysobalanaceae family (Coradin et al., 1985). A total of 167 secondary metabolites were reported so far for the plant family Chrysobalanaceae including triterpenes (lupane, oleanane, ursane and curcubitanetriterpenoids), diterpenes (kaurane and clerodanediterpenoids), steroids and polyphenols such as flavonoids (myricetin, quercetin, kaemferol, flavanones, flavanonols, flavanols, flavones) and chromones (Carnevale et al., 2013).

Neocarya macrophylla (Sabine) Prance formerly Parinari macrophylla Sabine, is a West African species used extensively in the Northern part of
Nigeria in ethno-medicine to treat numerous diseases which include asthma, skin infections, treatment of wounds, dysentery, inflammations, pulmonary troubles, ear and eye infections (Warra et al., 2013). In Nigerian traditional medicine, the fruit is used to treat diarrhoea, and could be eaten fresh or boiled with cereal (Arbonnier, 2004; Tidjani et al., 2010). The seed kernels are also eaten while the nuts are usually roasted and enjoyed like cashews or almonds (NRC, 2008). The stem bark is used to treat dysentery, cancer, tooth decay, breathing disorders and snake bites [Personal Communication], conjunctivitis and pain (Arbonnier, 2004). In Senegal, a cigarette prepared from the stem bark of $N$. macrophylla is used as remedy for snake bite (Mohagheghzadeh et al., 2006). The leaves may also be chewed or applied topically for the relief of pain (Tidjani et al., 2010) and it is also used in the treatment of snakebite [Personal Communication]. Decoction of the bark and leaves is used as mouth wash, internal troubles and for inflamed eye (Arbonnier, 2004; Tidjani et al., 2010). The roots are used in treatment of circumcision wounds, as antivenom and haemostatic agent (Arbonnier, 2004). Stigmasterol and Bis-(5, 7-diacetyl-catechin-4'-a- 
rhamnopyranoside) were isolated from the stem bark of the plant (Yusuf et al., 2015b).The leaves were reported to have anthelminthic (Barnabas et al., 2010) and antimicrobial (Audu et al., 2005; Halilu et. al., 2010) activities while the stem bark has antimicrobial (Yusuf et al., 2015c), analgesic (Yusuf et al., 2015d) and antivenin activities (Yusuf et al., 2015a). Recently, antimicrobial activity of stigmasterol from the stem bark of the plant was reported (Yusuf et al., 2018) and Olowo-Okere et al. (2018) also reported the antibacterial and anti-biofilm activities of the methanol leaf extract and its fractions against $S$. aureusand $P$. aureginosa. We now report the isolation and characterization of (-)-epicatechin from the ethylacetate fraction of the methanol stem bark extract of $N$. macrophylla.

\section{MATERIALS AND METHODS General Experimental Procedures}

NMR data were recorded on a Bruker AVANCE spectrometer $(600 \mathrm{MHz})$ with residual solvent as internal standard. Melting point was determined on an Electro thermal melting point apparatus. TLC was carried out using silica gel 60 GF $_{254}$ precoated aluminum sheets (Sigma Aldrich, Germany). Column chromatography was conducted using LOBA Cheme silica gel (60 200) mesh while gel filtration chromatography was performed using sephadex LH-20 (Sima, Spruce street, St. Louis, MO, USA). Spots on TLC plates were visualized by spraying with $10 \%$ $\mathrm{H}_{2} \mathrm{SO}_{4}$ followed by heating at $105^{\circ} \mathrm{C}$ for $10 \mathrm{~min}$.

\section{Plant Sample}

The stem bark of $N$. macrophylla was collected in October, 2015 at Jega Local Government Area of Kebbi State. It was identified at the Herbarium section, Department of Biological Sciences, Ahmadu Bello University by comparing with herbarium reference voucher specimen (No. 3197). The stem bark was shade dried, pulverized to powder, labelled and stored at room temperature for use.

\section{Extraction and Isolation}

The powdered stem bark (3000 g) was extracted with $90 \%$ methanol using maceration method for 6 days. The extract was evaporated in-vacuo using rotary evaporator at $40^{\circ} \mathrm{C}$ to yield a reddish-brown residue $(396 \mathrm{~g})$ subsequently referred to as the crude methanol extract (MES). Some part of MES $(200 \mathrm{~g})$ was dissolved in distilled water, filtered and partitioned successively with n-hexane (1 L), dichloromethane $(1 \mathrm{~L})$, ethylacetate $(2.5 \mathrm{~L})$ and $\mathrm{n}$ butanol $(2.5 \mathrm{~L})$ to obtain hexane fraction (HFS, $13.5 \mathrm{~g}$ ), dichloromethane fraction (DFS, $2.8 \mathrm{~g}$ ), ethylacetate fraction (EFS, $13.0 \mathrm{~g}$ ), n-butanol fraction (BFS, $32.0 \mathrm{~g}$ ) and the residual aqueous fraction (AFS), respectively. The ethylacetate fraction $(13.0 \mathrm{~g})$ was gradiently eluted in a silica gel packed column using different solvent combinations starting with hexane: ethylacetate (1:1), ethylacetate $(100 \%)$ to ethylacetate: methanol (8:2). Thirty (30) $\mathrm{mL}$ each of a total of 426 fractions were collected and combined based on their TLC profile to give (12) major fractions coded EA- EL. Repeated gel filtration of fraction EE with sephadex LH-20 using methanol led to the isolation of compound $1(11 \mathrm{mg})$.

\section{Characterization of Compound 1}

Compound 1 was subjected to characterization using chemical tests, melting point and spectroscopic analysis.

\section{RESULTS AND DISCUSSION Spectral data}

(-)-Epicatechin (1). Brown amorphous solid substance, m.p. $176-178{ }^{\circ} \mathrm{C} ;{ }^{1} \mathrm{H}-\mathrm{NMR}$ spectrum (in $\mathrm{CD}_{3} \mathrm{OD}$ ); $\delta 5.97(1 \mathrm{H}, \mathrm{d}, \mathrm{J}=2.2 \mathrm{~Hz}, \mathrm{H}-8), \delta 5.95$ $(1 \mathrm{H}, \mathrm{d}, \mathrm{J}=2.2 \mathrm{~Hz} . \mathrm{H}-6), \delta 2.91(\mathrm{HH}, \mathrm{dd}, \mathrm{J}=4.6,16.7$ $\mathrm{Hz}, \mathrm{H}-4 \mathrm{~b}), \delta 2.78$ (1H, dd, J=3.3, $16.7 \mathrm{~Hz}, \mathrm{H}-4 \mathrm{a})$, $\delta 4.85$ (1H, brs, H-2), $\delta 4.21(1 \mathrm{H}, \mathrm{m}, \mathrm{H}-3), \delta 7.00$ $\left(1 \mathrm{H}, \mathrm{d}, \mathrm{J}=1.7 \mathrm{~Hz}, \mathrm{H}-2^{\prime}\right), \delta 6.84(1 \mathrm{H}, \mathrm{dd}, \mathrm{J}=1.8,8.5$ $\left.\mathrm{Hz}, \mathrm{H}-6^{\prime}\right)$ and $\delta 6.82\left(1 \mathrm{H}, \mathrm{d}, 8.5 \mathrm{~Hz}, \mathrm{H}-5^{\prime}\right) .{ }^{13} \mathrm{C}-$ NMR (600 MHz, CD $\left.{ }_{3} \mathrm{OD}\right) ; \delta_{c} 155.9$ (C-5), 156.6 (C-7), 156.3 (C-9), 98.7 (C-10), 130.9 (C-1'), 144.4 (C-4'), 144.6 (C-3'), 78.5 (C-2), 66.1 (C-3), 27.9 (C-4), 95.1 (C-6), 94.6 (C-8), 113.9 (C-2'), $118.0\left(\mathrm{C}-6^{\prime}\right)$ and $114.6\left(\mathrm{C}-5^{\prime}\right)$. 
Compound 1 was obtained as a brown amorphous solid substance; the melting point range of the compound observed indicated its purity (John, 1964) and it tested positive to ferric chloride reagent suggesting the presence of phenolic nucleus (Silva et al., 1998). The ${ }^{1} \mathrm{H}-\mathrm{NMR}$ and ${ }^{13} \mathrm{C}-\mathrm{NMR}$ spectra of compound 1showed chemical shift values typical of flavonoids (Hye et al., 2009; Jung et al., 2012; Nasir et al., 2015). The presence of an $A X$ system (1, 2, 3, 5tetrasubstituted benzene ring $A$ ) was assigned from the protons at $\delta 5.97(1 \mathrm{H}, \mathrm{d}, \mathrm{J}=2.2 \mathrm{~Hz}, \mathrm{H}-8)$ and $\delta 5.95(1 \mathrm{H}, \mathrm{d}, \mathrm{J}=2.2 \mathrm{~Hz}, \mathrm{H}-6)$ while an $\mathrm{ABX}$ system (1, 3, 4-trisubstituted benzene ring $B$ ) was depicted via the protons at $\delta 7.00(1 \mathrm{H}, \mathrm{d}, \mathrm{J}=1.7$ $\left.\mathrm{Hz}, \mathrm{H}-2^{\prime}\right), \delta 6.84\left(1 \mathrm{H}, \mathrm{dd}, \mathrm{J}=1.8,8.5 \mathrm{~Hz}, \mathrm{H}-\mathrm{C}^{\prime}\right)$ and $\delta 6.82(1 \mathrm{H}, \mathrm{d}, \mathrm{J}=1.8,8.5, \mathrm{H}-5)$. The presence of an aliphatic ring was clearly discerned from the proton chemical shift values observed at $\delta 4.85$ $(1 \mathrm{H}, \mathrm{s}, \mathrm{H}-2)$ and $\delta 4.21(1 \mathrm{H}, \mathrm{m}, \mathrm{H}-3)$ representing an oxymethine and a carbinol proton respectively, consistent with a saturated ring C (Jung et al., 2012). Two hydrogen atoms with chemical shift values at $\delta 2.78(1 \mathrm{H}, \mathrm{dd}, 2.9,16.7 \mathrm{~Hz}, \mathrm{H}-4 \mathrm{a})$ and $\delta 2.91(1 \mathrm{H}, \mathrm{dd}, 4.6,16.7 \mathrm{~Hz}, \mathrm{H}-4 \mathrm{~b})$ assignable to $\mathrm{C}-4$ is characteristic of 3-flavan-type flavonoid (Hye et al., 2009; Jung et al., 2012; Nasir et al., 2015). The chemical shift value for $\mathrm{H}-2$ ( $\delta$ 4.85) which appeared as a broad singlet is an indication that compound 1 is an (-)-epicatechin rather than (+)-catechin (Petereit et al., 1991; De Mello et al., 1996). The ${ }^{13} \mathrm{C}-\mathrm{NMR}(600 \mathrm{MHz}$, $\mathrm{CD}_{3} \mathrm{OD}$ ) and DEPT experiments indicated the presence of 15 carbon atoms. Compound 1 exhibited seven aromatic methine carbon peaks at $\delta 94.5(\mathrm{C}-6), 95.1$ (C-8), 98.7 (C-10), 130.9 (C$\left.1^{\prime}\right), 113.9$ (C-2'), $114.6\left(\mathrm{C}-5^{\prime}\right)$ and $118.0\left(\mathrm{C}-6^{\prime}\right)$, five oxygenated carbon atoms at $\delta 156.3$ (C-5), 155.9 (C-7), 156.6 (C-9), 144.4 (C-4') and 144.6 $\left(\mathrm{C}-3^{\prime}\right)$ and the three aliphatic carbons at $\delta 78.5$
(C-2), 66.1 (C-3) and the methylene carbon at $\delta$ 27.9 (C-4) further suggested the compound 1 to be an epicatechin (Antonelli etal., 2007; Abdullahi etal., 2017). The absence of a downfield signal at around $\delta 82(\mathrm{C}-2)$ confirms compound 1 to be an (-)-epicatechin rather than (+)-catechin(Petereitet al., 1991; De Mello et al., 1996).

The results of the 2D-NMR spectroscopy of compound 1 were used to assign the carbon atoms with their respective protons and established the connectivity between the various protons and carbons within the molecule. HSQC experiment established the attachment of various protons to their respective carbons, the proton at $\delta_{H} 4.85$ correlated with $\delta_{C} 78.5$ and $\delta_{H} 2.91,2.78$ correlated with $\delta_{c} 27.9$ (Table 1). The ${ }^{1} \mathrm{H}-{ }^{1} \mathrm{H}$ COSY established the correlations between the protons at $\delta 4.21(\mathrm{H}-3) \# \delta 2.78(\mathrm{H}-4 \mathrm{a}), 2.91(\mathrm{H}-$ $4 b)$ and $\delta 2.78(\mathrm{H}-4 \mathrm{a})$ and $2.91(\mathrm{H}-4 \mathrm{~b})$ which confirmed the assignment of ring $C$ while the cross peaks correlations observed between $\delta$ $7.00\left(\mathrm{H}-2^{\prime}\right)$ and $\delta 6.84\left(\mathrm{H}-6^{\prime}\right)$ further substantiate the assignment of ring $\mathrm{B}$. The assignment of the protons, carbons and their linkages in the molecule was confirmed through the cross peaks detected on the HMBC spectrum (Table 1, Figure 2) which further confirmed the structure of compound 1 as an (-)-epicatechin (Figure 1). Comparison with a reference NMR data (Orisakeye and Olugbade, 2014) in Table 2 showed a good match and based on the above, the structure of compound 1 was confirmed to be (2R,3R)-3,4-dihydro-2-(3,4-dihydroxyphenyl)-2Hchromene-3,5,7-triol or (-)-epicatechin (Figure 1). Epicatechin has been reported to possess different pharmacological actions such as cardiovascular and neuropsychological effects (Bernatova, 2018), antioxidant, antimicrobial (Maria John et al., 2011) activities among others. 
Table 1: 1D and 2D NMR spectral data summary for compound 1

\begin{tabular}{|c|c|c|c|c|c|}
\hline Position & $\delta^{1} \mathrm{H}$ & $\delta^{133} \mathrm{C}$ & DEPT & $\cos Y$ & HMBC \\
\hline 1 & - & - & - & - & - \\
\hline 2 & 4.85 & 78.5 & $\mathrm{CH}$ & - & C1', C5', C6' \\
\hline 3 & 4.21 & 66.1 & $\mathrm{CH}$ & H-4a, H-4b & C10 \\
\hline \multirow[t]{2}{*}{4} & 2.91 & 27.9 & $\mathrm{CH}_{2}$ & $\mathrm{H}-4 \mathrm{a}$ & $\mathrm{C} 9, \mathrm{C} 10, \mathrm{C} 3, \mathrm{C} 2$ \\
\hline & 2.78 & & $\mathrm{CH}_{2}$ & $H-4 b$ & $\mathrm{C} 9, \mathrm{C} 10, \mathrm{C} 3, \mathrm{C} 2$ \\
\hline 5 & & 155.9 & C & - & \\
\hline 6 & 5.95 & 95.1 & $\mathrm{CH}$ & - & C5, C6, C10 \\
\hline 7 & - & 156.6 & C & - & - \\
\hline 8 & 5.97 & 94.5 & $\mathrm{CH}$ & - & $\mathrm{C7}, \mathrm{C} 8, \mathrm{C} 9$ \\
\hline 9 & - & 156.3 & C & - & \\
\hline 10 & - & 98.7 & C & - & \\
\hline $1^{\prime}$ & - & 130.9 & C & - & \\
\hline $2^{\prime}$ & 7.00 & 113.9 & $\mathrm{CH}$ & $H-6^{\prime}$ & C4', C6', C2 \\
\hline $3^{\prime}$ & - & 144.6 & C & . & \\
\hline $4^{\prime}$ & - & 144.4 & C &  & \\
\hline $5^{\prime}$ & 6.82 & 114.6 & $\mathrm{CH}$ & - & $C 3^{\prime}, C 5^{\prime}, \mathrm{C} 2$ \\
\hline $6^{\prime}$ & 6.84 & 118.0 & $\mathrm{CH}$ & H-2' & C1', C2', C3' \\
\hline
\end{tabular}

Table 2: Comparison of ${ }^{1 \mathrm{H}}$ and ${ }^{13} \mathrm{C}-\mathrm{NMR}$ data of compound 1 with reported literature

\begin{tabular}{ccccc}
\hline Position & $\delta^{1} \mathrm{H}(\mathrm{J} \mathrm{in} \mathrm{Hz})$ & $\delta^{13} \mathrm{C}$ & $\delta^{1} \mathrm{H}$ & $\delta^{13} \mathrm{C}$ \\
\hline \multicolumn{5}{c}{ Compound 1Literature } \\
\hline 1 & - & - & - & - \\
2 & $4.85(1 \mathrm{H}, \mathrm{brs})$ & 78.5 & $4.87(\mathrm{brs})$ & 78.8 \\
3 & $4.21(1 \mathrm{H}, \mathrm{m})$ & 66.1 & $4.20(\mathrm{~m})$ & 66.3 \\
4 & $2.91(1 \mathrm{H}, \mathrm{dd}, 2.9,16.7)$ & 27.9 & $2.72(\mathrm{dd}, 3.3,16.7)$ & 28.3 \\
& $2.78(1 \mathrm{H}, \mathrm{dd}, 4.616 .7)$ & \multicolumn{4}{c}{$2.85(\mathrm{dd}, 4.5,16.7)$} \\
5 & - & 155.9 & - & 156.9 \\
6 & $5.95(1 \mathrm{H}, \mathrm{d}, 2.2)$ & 95.1 & $6.02(\mathrm{~d}, 2.2)$ & 95.1 \\
7 & - & 156.6 & - & 156.5 \\
8 & $5.97(1 \mathrm{H}, \mathrm{d}, 2.2)$ & 94.5 & $5.91(\mathrm{~d}, 2.2)$ & 95.0 \\
9 & - & 156.3 & - & 156.9 \\
10 & - & 98.7 & - & 99.1 \\
$1^{\prime}$ & - & 130.9 & - & 131.6 \\
$2^{\prime}$ & $7.00(1 \mathrm{H}, \mathrm{d}, 1.7)$ & 113.9 & $7.05(\mathrm{~d}, 1.7)$ & 114.6 \\
$3^{\prime}$ & - & 144.6 & - & 144.8 \\
$4^{\prime}$ & - & 144.4 & - & 144.6 \\
$5^{\prime}$ & $6.82(1 \mathrm{H}, \mathrm{d}, 8.5)$ & 114.6 & $6.78(\mathrm{~d}, 8.1)$ & 114.8 \\
$6^{\prime}$ & $6.84(1 \mathrm{H}, \mathrm{dd}, 1.8,8.5)$ & 118.0 & $6.84(\mathrm{dd}, 1.7,8.1)$ & 118.7 \\
\hline
\end{tabular}






Figure 1: Structure of epicatechin

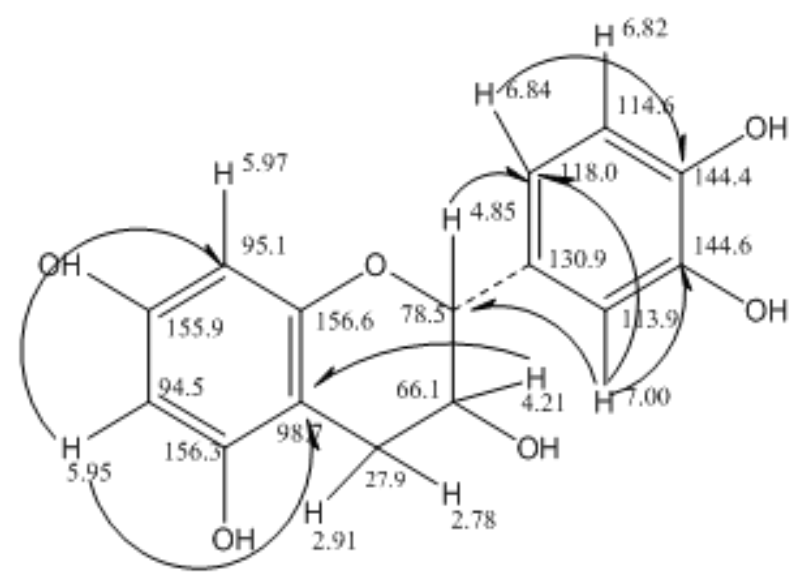

Figure 2: Some major HMBC correlations of epicatechin

\section{CONCLUSION}

The isolated and characterized compound epicatechin from the stem bark of $N$. macrophylla to the best of our knowledge is the first report of isolation of this compound from the plant.

\section{ACKNOWLEDGEMENT}

Our special gratitude to Mr. Dilip Jagjivan, School of Chemistry and Physics, University of Kwa-Zulu Natal- Durban, South Africa for running the 1Dand 2D-NMR spectroscopy

\section{CONFLICT OF INTERESTS}

None declared.

\section{REFERENCES}

Abdullahi, S. M., Musa, A. M., Abdullahi, M. I., Sani, Y. M. and Atiku, I. (2017). Catechin from the leaf extract of Ziziphus mucronata Willd. (Rhamnaceae). Nigerian Journal of Pharmaceutical Sciences, 16(2): 01-05.

Antonelli, U. T. M., Yamaguti, E., Uemura, L. M., Nakamura, C. V., Dias Filho, B. P., Palazzo De Mello, J. C. (2007). Chemical and Microbiological Study of Extract from Seeds of Guarana (Paulliniacupana var. sorbilis). Latin American Journal of Pharmacy, 26(1): 5-9.

Arbonnier, M. (2004). Trees, Shrubs and Lianas of West African Dry Zones. Cidrad, Margraf Publishers. Gmbh, MNHN, Paris, France. Pp. 250-251.

Audu, O. T., Oyewale, A. O. and Amupitan, J. O. (2005). The biological activities of secondary metabolites of Parinari macrophylla Sabine. ChemClass Journal, 2: 19-21.

Barnabas, B. B., Mann, A., Ogunrinola, T. S. and Anyanwu, P. E. (2010). Screening of anthelminthic activities from extracts of Zanthoxylum zanthoxyloides, Neocarya macrophylla and Celosia laxa against Ascaris infection in rabbits. International Journal of Applied Research in Natural Products, 3(4): 1-4.

Bernatova, I. (2018). Biological activities of (-)epicatechin and (-)-epicatechincontaining foods: Focus on cardiovascular and neuropsychological health. Biotechnology Advances, 36(3): 666-681.

Carnevale, F.N., Alan, C.P., da Silva, B. V. and lan, C. G. (2013). Chrysobalanaceae: secondary metabolites, Ethnopharmacology and pharmacological potential. Phytochemistry Reviews, 12: 121-146.

Coradin, L., Giannasi, D. E., Prance, A. T. (1985). Chemosystematic studies in the 
Chrysobalanaceae. Flavonoids in Parinari. Britton, 37: 169-178.

De Mello, J. P., Petereit, F. and Nahrstedt, A. (1996). Dictionary of Food Compounds. Phytochemistry, 41: 807-813.

Halilu, M. E., Abah, J. O., Almustapha, N. L. and Achor, M. (2010). Phytochemical screening and mineral element analysis of the root bark of Parinari macrophylla Sabine (Chrysobalanaceae) and its effect on microorganisms. Continental Journal of Biological Sciences, 3: 46-50.

Hye, M. A., Taher, M. A., Ali, M. Y., Ali, M. U. and Shahed, Z. (2009). Isolation of $(+)-$ Catechin from Acacia catechu (Cutch Tree) by a Convenient Method. Journal of Scientific Research, 1(2): $300-305$.

John, D. R. (1964). Melting point tables of organic compounds (Utermark, Walter; Schicke, Walter). Journal of Chemical Education, 41(8): A590.

Jung, E. K., Sang, S. K., Chang-Gu, H. and Nam, H. L. (2012). Antioxidant Chemical Constituents from the Stems of Cleyera japonica Thunberg. International Journal of Pharmacology, 8(5): 410-415.

Maria John, K. M., Rajesh, J., Mandal, A. K. A. and Sampath, N. (2011). Antioxidant and antimicrobial activity of individual catechin molecules: A comparative study between gallated and epimerized catechin molecules. European Journal of Experimental Biology, 1(3):145-153.

Mohagheghzadeh, A., Faridi, P., ShamsArdakani, M. and Ghasemi, Y. (2006). Medicinal smokes. Journal of Ethnopharmacology, 108: 161-184.

Nasir, T., Muhammad, S. S., Aliyu, M. M., Sani, M. Y., James, D. H. and Abdullahi, M. I. (2015). A novel antimicrobial flavonoid from the stem bark of Commiphora pedunculata (Kotschy and Peyr.) Engl., Natural Product Research: Formerly Natural Product Letters; 1-4. DOI: 10.1080/14786419.2016.1274892.
National Research Council. (NRC) (2008). Lost crops of Africa. Volume 3, Fruits. National Academic Press. pp. 262 - 269.

Olowo-Okere, A., Yusuf, A. J., Shuaibu, A. B., Abdullahi, M. I., Aleku, G. A., Nuhu, T., Ungokore, H. Y., llyas, U., Ogunyinka, I. A., Atata, R. F. (2018). Antibacterial and anti-biofilm activities of Neocarya macrophylla against clinical bacterial isolates. Nigerian Journal of Pharmaceutical Research, 14(1): 111 119.

Orisakeye, O. T., Olugbade, T. A. (2014). Epicatechin and Procyanidin B2 in the stem and root bark of Sterculia tragacantha Lindl (Sterculiaceae). Medicinal Chemistry, 4(2): 334-337.

Petereit, F., Kolodziey, H., Nahrstedt, A. (1991). Flavon-3-ols and Proanthocyanidins from Citus incamus. Phytochemistry, 30: 981.

Prance, G. T. (1988). Chrysobalanaceae. Royal Botanic Gardens, Kew. Flora Neotropica. 9: 1 - 409 .

Silva, G. L., Lee, I., Douglas, K. A. (1998). Special problems with extraction of plants. In: Cannell J.P.R (eds). Natural Products Isolation, Human Publishers, New Jersey USA. 251-293.

Tidjani, A., Issoufou, A., Mohamed, T. K., Kexue, Z. and Huiming, Z. (2010). Chemical and Nutrient Analysis of Gingerbread Plum (Neocarya macrophylla) seeds. Advanced Journal of Food Science and Technology, 2(4): 191-195.

Warra, A. A., Umar, R. A., Sani, I., Gafar, M. K., Nasiru, A. and Ado, A. (2013). Preliminary Phytochemical Screening and Physicochemical Analysis of Ginger bread plum (Parinari macrophylla) Seed oil. Journal of Pharmacognosy and Phytochemistry, 1(2): 20-25.

Yakandawala, D, Morton, C. M. and Prance, G. T. (2010). Phylogenetic relationships of the Chrysobalanaceae inferred from chloroplast, nuclear, and morphological data. Annals of the Missouri Botanical Garden, 97: 259-281. 
Yusuf, A. J., Abdullahi, M. I., Haruna, A. K., Idris, A. Y. and Musa, A. M. (2015b). Isolation and characterization of stigmasterol and Bis-(5,7-diacetyl-catechin-4'-arhamnopyranoside) from the stem bark of Neocarya macrophylla (Sabine) Prance (Chrysobalanaceae). Nigerian Journal of Basic and Applied Sciences, 21(1): 1522.

Yusuf, A. J., Abdullahi, M. I., Aleku, G. A., Ibrahim, I. A. A., Alebiosu, C. O., Yahaya, M. et al. (2018). Antimicrobial activity of stigmasterol from the stem bark of Neocarya macrophylla. Journal of Medicinal Plants for Economic Development, 2(1): a38: 1-5.

Yusuf, A.J., Abdullahi, M. I., Haruna, A. K., Idris, A. Y. and Musa, A. M. (2015a). Preliminary phytochemical screening, toxicological and antivenin property of the stem bark of Neocarya macrophylla on Naja nigricollis venom. African Journal of Pharmaceutical Research and Development, 7(1): 6-10.
Yusuf, A. J., Abdullahi, M. I., Haruna, A. K., Musa, A. M., Abdullahi, M. S., Ibrahim, Z. Y. Y., Halilu, M. E. and Odiba, O. J. (2015c). Phytochemical and antimicrobial evaluation of the methanol stem bark extract of Neocarya macrophylla. Journal of Chemical and Pharmaceutical Research, 7(1): 477-481.

Yusuf, A. J., Abdullahi, M. I., Haruna, A. K., Musa, A. M., Ibrahim, Z. Y. Y. and Uba, A. (2015d). Acute toxicity studies and evaluation of analgesic property of the methanol stem bark extract of Neocarya macrophylla. Journal of Applied Pharmaceutical Sciences, 5(Suppl1): 061-064. 